\title{
Influences of riverine humic substances on bacteria, protozoa, phytoplankton, and copepods in a coastal plankton community
}

\author{
Per Carlsson ${ }^{1, *}$, Edna Granéli ${ }^{1}$, Patricia Tester ${ }^{2}$, Laurita Boni ${ }^{3}$

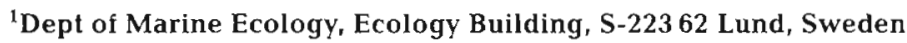 \\ ${ }^{2}$ National Marine Fisheries Service, NOAA, Southeast Fisheries Science Center, Beaufort Laboratory, Beaufort, \\ North Carolina 28516, USA \\ ${ }^{3}$ University of Bologna, Department of Biology, Via Irnerio 42, I-40126 Bologna, Italy
}

\begin{abstract}
The effects of additions of humic substances (derived from river water) on bacteria, protozoa, phytoplankton, and copepods in a coastal plankton community from the Skagerrak (west coast of Sweden) were studied in an enclosure experiment. Bacterial numbers and bacterial production were significantly higher in the humic treatment compared with non-humic treatment. Tintinnids and oligotrich ciliates also attained higher densities in the humic treatment than in non-humic treatment, probably reflecting higher food availability due to the increased bacterial production. Phytoplankton biomass and primary production were slightly higher in the humic treatment compared with the nonhumic treatment. The growth of dinoflagellates and small flagellates was enhanced by humic addition. The number of copepods and nauplii became significantly lower in the humic treatments. Thus, the humic addition affected the 'microbial loop' positively, but the increase in nutrient regeneration substantially increased neither phytoplankton growth nor copepod production.
\end{abstract}

KEY WORDS: Humic substances - Organic nitrogen · Microbial loop · Dinoflagellates

\section{INTRODUCTION}

Nutrient availability and grazing are both factors which have important effects on the structure of marine phytoplankton communities. The two are interconnected because nutrient availability is partly dependent on regeneration of nutrients by grazers. Often, only inorganic nutrients are considered to be important for phytoplankton growth, but organic bound nutrients may also be of significance. Phytoplankton may take up nitrogen in the form of organic compounds such as urea (Sahlsten et al. 1988) or amino acids (Flynn \& Butler 1986). Inorganic nitrogen sources include nitrite or nitrate produced by bacterial mineralization (Tupas \& Koike 1990) and ammonia produced by excretion by grazers (Båmstedt 1985. Probyn 1987. Caron \& Goldman 1990).

\footnotetext{
•E-mail: per.carlsson@marinecol.lu.se
}

A large pool of the dissolved organic nitrogen in coastal areas occurs in humic substances, which leak from soils and are transported by rivers into coastal waters. The amount of humic substances entering coastal waters can be significant in areas where the drainage area is dominated by forests (Andersson et al. 1991). Indeed, humic substances constitute the largest fraction of the dissolved organic matter (DOM) in most natural waters (Thurman 1985). Humic substances are, however, thought to be relatively resistant to bacterial degradation (Fenchel \& Blackburn 1979, Geller 1983), so that low-molecular weight DOM produced by phytoplankton is thought to be the main carbon source for bacteria (Larsson \& Hagström 1979, Chrost et al. 1989, Vadstein et al. 1989). On the other hand, humic substances can support bacterial growth in freshwater systems (Tranvik 1988, Moran \& Hodson 1990) and thus might be utilized to some extent by bacteria in coastal waters. For example, humic substances contain nitrogen ( 3 to $6 \%$; Rashid 1985) and might therefore be 
a potential nitrogen source for phytoplankton. Carlsson et al. (1993) found in enclosure experiments with coastal water containing natural phytoplankton communities (larger zooplankton were excluded) that additions of humic substances isolated from river water lead to increases in phytoplankton biomass. This might have resulted because bacteria used the humic substances as substrates and were then consumed by heterotrophic grazers, which in turn excreted ammonia (Carlsson et al. 1993). In addition, photooxidation of humic substances may occur (Kieber et al. 1990). This process may produce labile compounds which might then be taken up by phytoplankton directly.

To see if riverine humic substances can be utilized by marine bacteria and, if so, the resulting increased bacterial production would increase phytoplankton and zooplankton production via the 'microbial loop' (Azam et al. 1983), we performed an enclosure experiment during late summer. We looked at the growth of bacteria, the changes in phytoplankton species composition. bacterial production, phytoplankton primary production and the growth of protozoa and copepods.

\section{MATERIALS AND METHODS}

Water from $1 \mathrm{~m}$ depth from the Gullmar Fjord, on the Swedish west coast, was pumped through a $100 \mu \mathrm{m}$ nylon net using a submersible pump on 4 August 1992. The water was used to fill sixteen $100 \mathrm{l}$ polyethene cylinders, which had been cleaned with Deconex ${ }^{\mathrm{TM}}$ detergent, kept in seawater for $24 \mathrm{~h}$ and then thoroughly rinsed with seawater to remove any toxins from the plastic. The cylinders were placed in a pool which was kept at the in situ temperature $\left(18\right.$ to $\left.19^{\circ} \mathrm{C}\right)$ by flow-through of surface sea water from nearby. The cylinders were covered with a $0.1 \mathrm{~mm}$ polyethene film to prevent aerial contamination and subjected to natural light conditions.

The water in the cylinders had a salinity of $25.5 \%$ and the nutrient concentrations were as follows: $\mathrm{NO}_{3}{ }^{-}$, $0.25 \mu \mathrm{mol} \mathrm{l}{ }^{-1} ; \mathrm{NH}_{4}{ }^{+}, 0.3 \mu \mathrm{mol} \mathrm{l}^{-1} ; \mathrm{PO}_{4}{ }^{3-}, 0.05 \mu \mathrm{mol} \mathrm{l}^{-1}$; $\mathrm{Si}(\mathrm{OH})_{4}, 0.4 \mu \mathrm{mol} \mathrm{l}^{-1}$. Earlier experiments have shown that, without nutrient additions, nutrient depletion will occur in experiments like these after only a short time because of nutrient uptake by the biofilm that establishes on the enclosure walls (Santschi 1982). Thus, to keep the phytoplankton from becoming nutrient limited during the initial part of the experiment, nutrients were added to the following concentrations in all cylinders: $\mathrm{NH}_{4}{ }^{+}, 4.0 \mu \mathrm{mol} \mathrm{I}{ }^{-1} ; \mathrm{PO}_{4}{ }^{3-}, 2.0 \mu \mathrm{mol} \mathrm{l} \mathrm{l}^{-1}$; and $\mathrm{Si}(\mathrm{OH})_{4}, 4.0 \mu \mathrm{mol} \mathrm{l}^{-1}$. The surplus addition of $\mathrm{P}$ compared to $N(N / P=2)$ was made to ensure that P-limitation of phytoplankton biomass production did not occur. In earlier experiments it was found that $\mathrm{N}$ in humic substances could be utilized by phytoplankton (Carlsson \& Granéli 1993), and addition of excess P should have made it possible for the plankton to use all 'degradable' $\mathrm{N}$ in the humic substances. Trace metals, iron and EDTA were added to all flasks at concentrations corresponding to the $f$ medium (Guillard \& Ryther 1962) (at $1 / 20$ of the original concentration).

Zooplankton were caught with a $100 \mu \mathrm{m}$ mesh size net towed at 2 to $4 \mathrm{~m}$ depth on 2 August. The zooplankton were placed in a $50 \mathrm{l}$ carboy and were kept at 18 to $20^{\circ} \mathrm{C}$, with aeration. The natural concentration of zooplankton was determined from a quantitative net tow with the $100 \mu \mathrm{m}$ mesh size net hauled vertically through a $10 \mathrm{~m}$ water column. On 4 August, dead animals were gently siphoned off from the zooplankton carboy, and the living zooplankton were concentrated by filtration using a $100 \mu \mathrm{m}$ net.

The aim was to add copepods to all 16 cylinders in order to reach the natural concentration. However, the zooplankton counts from Day 1 showed that there were 80 to 90 ind. $1^{-1}$ present in the cylinders, which was approximately 3 times the ambient density. Concentrations of Oithona spp. observed elsewhere have varied from 0.5 to 2 ind. $\mathrm{l}^{-1}$ in the Barents Sea (González \& Smetacek 1994), 0 to 40 ind. $\mathrm{l}^{-1}$ in the open ocean (Davis et al. 1992) and up to more than 1000 ind. $I^{-1}$ in Japanese coastal waters (Uchima unpubl., cited in Uchima 1988). Thus, the copepod concentrations used in this experiment do occur under natural conditions.

Humic substances were added to 8 of the cylinders. The addition of humic substances increased the dissolved organic carbon (DOC) concentration of the water from 5.0 to $7.8 \mathrm{mg} \mathrm{l}^{-1}$.

The humic substances were isolated from water sampled close to the mouth of the river Fylleån in the county of Halland, Sweden. The separation and concentration of humic substances were done using the methods described by Thurman \& Malcolm (1981) and Petersen et al. (1987). The water was acidified to $\mathrm{pH} 1.8$ with sulphuric acid and filtered through 50 and $1 \mu \mathrm{m}$ cartridge filters (Brunswick Technetics Filterite). The filtered water was then passed through a XAD-8 resin (Amberlite ${ }^{\top M}$ ) in a glass column at a rate of $100 \mathrm{ml} \mathrm{min}^{-1}$. By the commonly used definition, aquatic humus is the organic material which adheres to a macroporous resin (such as XAD-8) at $\mathrm{pH} 2$ (Thurman 1985). The humic material was then desorbed by back flushing the column with 2.5 bed volumes of $0.1 \mathrm{M} \mathrm{NaOH}$ followed by immediate acidification to $\mathrm{pH} 2.5$. The $\mathrm{pH}$ was then adjusted to 7.0 with $\mathrm{NaOH}$, and the humic substances were frozen until use. Analysis of total nitrogen in the humic substances, using the method described by Solórzano \& Sharp (1980), showed that it contained 1.8\% N (by 
weight). An addition of humic substances which gave a concentration increase of $2.8 \mathrm{mg} \mathrm{l}^{-1}$ of DOC in the cylinders was thus equivalent to a final concentration of $3.6 \mu \mathrm{mol} \mathrm{I}^{-1} \mathrm{~N}$ (excluding the initial nitrogen content of the seawater).

The cylinders were sampled daily. Before sampling, the cylinders were gently stirred by moving a Secchi disc through the water column to ensure that it was thoroughly mixed.

Daily measurements of chlorophyll a (chl a) concentration were made using ethanol extracts of filters (Jespersen \& Christoffersen 1987). Samples (10 to $20 \mathrm{ml}$ ) were filtered onto Whatman GF/F filters, and chl a fluorescence was measured using a Turner 112 filterfluorometer. When this extraction is used, the fluorescence of humic substances which can otherwise disturb in vivo chl a measurements (Carlson \& Shapiro 1981) is avoided. The fluorescence measurements of chl a were calibrated to absolute chl a values using spectrophotometric analysis of extracted chl a. This was done twice (Days 1 and 9 of the experiment), using a water sample which contained equal proportions from all cylinders.

Primary production was measured as ${ }^{14} \mathrm{C}$ uptake using the method of Ertebjerg-Nielsen \& Bresta (1984). Two $\mu \mathrm{Ci}$ of radioactive $\mathrm{NaH}^{14} \mathrm{CO}_{3}\left({ }^{14} \mathrm{C}\right.$-Centralen Copenhagen) was added to $25 \mathrm{ml}$ glass flasks and incubated for $2 \mathrm{~h}(12: 00$ to $14: 00 \mathrm{~h})$. The flasks were incubated at $0.5 \mathrm{~m}$ in the pool, outside the cylinders. Light measurements were carried out with a QSL-100 spherical quantameter (Biospherical Instruments, Inc.). Light intensity (PAR) varied between 80 and $2100 \mu \mathrm{E} \mathrm{m}^{-2} \mathrm{~s}^{-1}$ during the incubations, depending on the degree of cloudiness. Primary production was calculated as $\mu \mathrm{g} \mathrm{Cl}^{-1} \mathrm{~h}^{-1}$ (dark bottle values were subtracted from light bottle values).

Bacterial production was measured using ${ }^{3} \mathrm{H}$-thymidine (specific activity $40 \mathrm{Ci} \mathrm{mmol}^{-1}$; Amersham Corp.) according to Fuhrman \& Azam $(1980,1982)$. The final concentration of the isotope was $10 \mathrm{nmol} \mathrm{1^{-1 }}$, which should have been sufficient to reach saturation uptake (Heinänen 1993).

Nutrients $\left[\mathrm{NO}_{3}{ }^{-}, \mathrm{NH}_{4}{ }^{+}, \mathrm{PO}_{4}{ }^{3-}\right.$ and $\left.\mathrm{Si}(\mathrm{OH})_{4}\right]$ were analyzed using standard procedures for seawater (UNESCO 1983). $\mathrm{NO}_{3}^{-}$was analyzed with an autoanalyzer (TRAACS) and $\mathrm{NH}_{4}{ }^{+}, \mathrm{PO}_{4}{ }^{3-}$ and $\mathrm{Si}(\mathrm{OH})_{4}$ were analyzed manually.

Zooplankton were sampled on Days 1, 3 and 9 of the experiment. Between 2 and 51 of water was sampled. The water was screened through a $30 \mu \mathrm{m}$ nylon net, in order not to miss any nauplii present, and preserved in $35 \mathrm{ml}$ of $5 \%$ Lugol's solution. Between 20 and $100 \%$ of the total volume was counted depending on the numbers of zooplankton present. At least 100 animals were counted at $100 \times$ magnification, using a Nikon TMS inverted microscope. The following categories of zoo- plankton were used: copepods, copepodite stages $C_{1}$ to $\mathrm{C}_{5}$ of the dominant copepod Oithona similis, cyclopoids, calanoids, harpacticoids, nauplii, cladocerans and tintinnids. Since copepods and copepodite stages of Oithona similis, along with nauplii, totally dominated the zooplankton (more than $98 \%$ of the counted individuals), only data for these categories are presented.

Phytoplankton samples were preserved with acidified Lugol's solution and cell counting was performed with a Nikon Diaphot inverted microscope using the method described by Utermöhl (1958). Cell counts were made on the initial day and Days 3, 6, 9 and 10 for all replicates. At least 50 , but often more than 400 cells were counted (depending on the abundance in the samples) for each phytoplankton species/group, giving a standard deviation of $\pm 28 \%$ or $\pm 10 \%$ respectively. Oligotrich ciliates and tintinnids were also counted in the phytoplankton samples. The dimensions of at least 10 cells of each phytoplankton species/group were measured for calculation of plasma volume of diatoms and cell volume of other species, following stereometric formulas in Edler (1979). To convert $\mu \mathrm{m}^{3}$ to $\mathrm{pg} \mathrm{C}$ the conversion factors 0.13 for dinoflagellates (Smetacek 1975) and 0.11 for all other species were used (Strathmann 1967).

Growth rates $\left(\mathrm{d}^{-1}\right)$ for phytoplankton and ciliates were calculated according to the following formula: $\mu=\ln \left(N_{t 1} / N_{t 2}\right) / \Delta t$, where $N_{t 1}$ and $N_{t 2}$ are cell numbers at 2 different times during the experiment where positive growth occurred and $\Delta t$ is the time interval (in days) between $N_{t 1}$ and $N_{t 2}$.

Bacterial counts were made according to the method described by Porter \& Feig (1980) using the fluorochrome DAPI and a Nikon Optiphot epifluorescence microscope equipped with the following filters: excitation, $365 \mathrm{~nm}$; barrier filter, $400 \mathrm{~nm}$; dichroic mirror, $400 \mathrm{~nm}$.

Statistical analyses of differences between growth rates for phytoplankton and ciliates, chl a concentrations, primary production, bacterial numbers and bacterial production in the cylinders with and without additions of humic substances were carried out using 2-tailed paired $t$-tests.

\section{RESULTS}

\section{Nutrients}

Approximately $2 \mu \mathrm{mol} \mathrm{l}^{-1}$ of the added ammonium $\left(4 \mu \mathrm{mol} \mathrm{l}^{-1}\right)$ was taken up by the phytoplankton/bacteria between the addition on the evening of the first day of the experiment and the first measurements early the next day. During the first $3 \mathrm{~d}$ of the experiment, ammo- 
nium concentrations became low $(0.10$ to $0.20 \mu \mathrm{mol}$ $\left.1^{-1}\right\}$. The nitrate + nitrite concentrations also became low $\left(0.02\right.$ to $\left.0.10 \mathrm{umol} \mathrm{l}^{-1}\right)$ after 3 to $4 \mathrm{~d}$, while the phosphate concentrations stabilized at 1.3 to $1.5 \mu \mathrm{mol} \mathrm{l^{-1 }}$ after $6 \mathrm{~d}$. The N/P ratio of inorganic $\mathrm{N}$ and $\mathrm{P}$ thus became around 0.10 to 0.25 . Silicate concentrations decreased from 4.0 to $0.4-0.5 \mathrm{\mu mol} \mathrm{l}^{-1}$ during the first $4 \mathrm{~d}$ of the experiment. There were no significant differences in nutrient concentrations between the 2 treatments at any time.
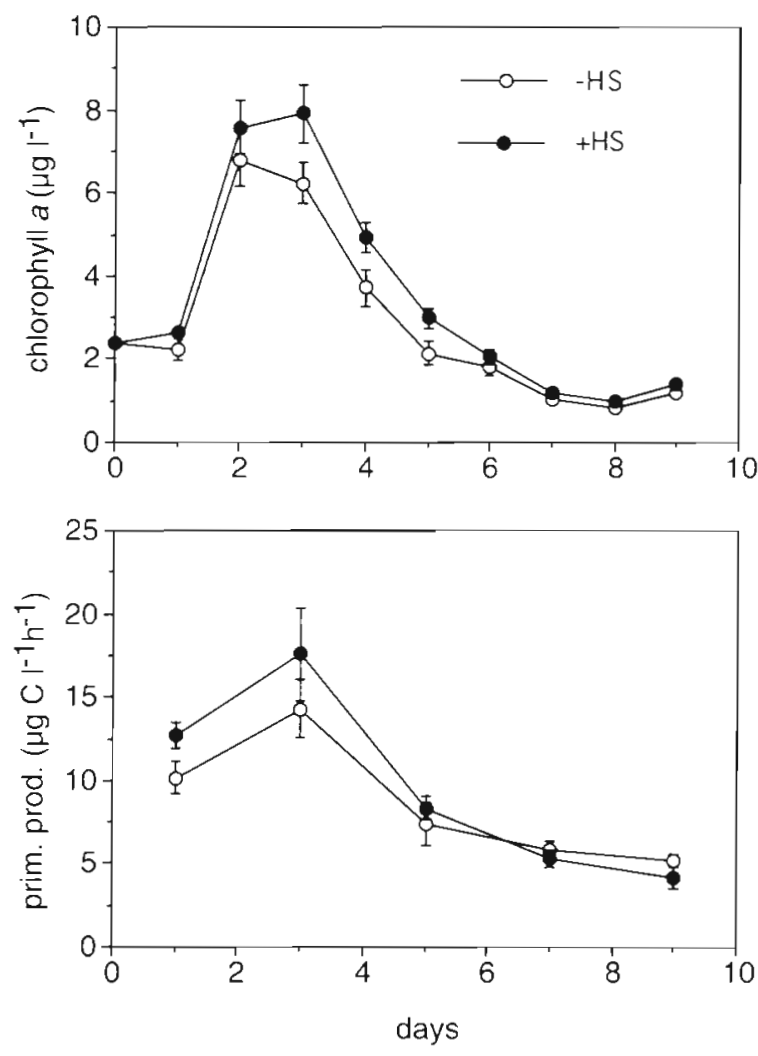

Fig. 1. Changes in chlorophyll $a$ and primary production in treatments with (+HS) or without (-HS) addition of humic substances. Mean \pm SD of 8 replicates

\section{Chlorophyll a}

Chl a concentrations increased from approximately 2 to $8 \mu \mathrm{g} \mathrm{l}^{-1}$ during the first day of the experiment in the humic and non-humic treatments (Fig. 1). After Day 2 or $3, \mathrm{chl}$ a concentrations decreased continuously until the end of the experiment. Chl a concentrations were slightly, but significantly, higher in the humic treatment than in the non-humic treatment throughout the experiment $(p<0.001)$.

\section{Primary production}

The rate of carbon fixation increased in both treatments during the first $3 \mathrm{~d}$ of the experiment. which was a consequence of the addition of nutrients and increase in phytoplankton biomass (Fig. 1). Primary production rates were higher in the humic treatment compared with the non-humic treatment on Days 1,3 and $5(\mathrm{p}<$ 0.01 ). After Day 3 , primary production rates decreased in both treatments and attained lower values in the humic treatment than in the non-humic treatment.

\section{Bacterial numbers and production}

The initial concentration of bacteria in the cylinders was approximately $1.0 \times 10^{6}$ cells ml $^{-1}$ (Fig. 2). The number increased between Days 1 and 2 in both treatments. The increase was significantly higher in the treatment where humic substances had been added ( $\mathrm{p}$ $<0.001$ ). After this initial increase, bacterial numbers remained approximately unchanged until Day 6 , after which a second increase occurred between Days 6 and 10 (from approximately $1.5-2$ to $3-5 \times 10^{6}$ cells ml ${ }^{-1}$ ).
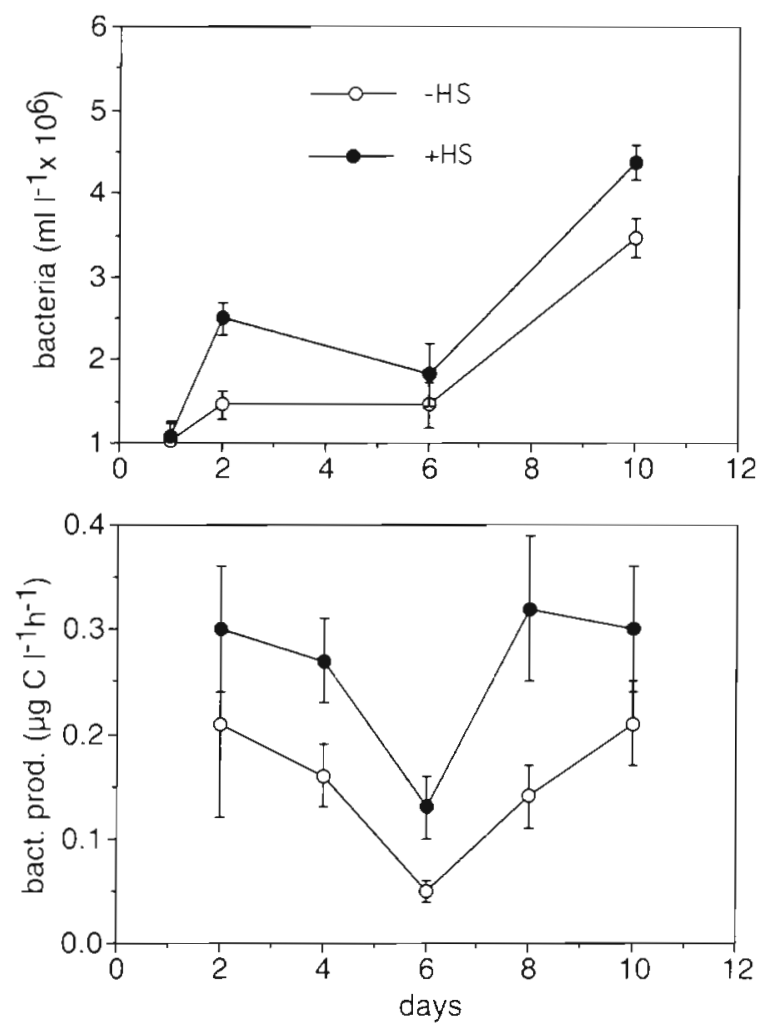

Fig. 2. Changes in bacterial numbers and bacterial production in treatments with $(+\mathrm{HS})$ or without (-HS) humic substances added. Mean \pm SD of 8 replicates 
This increase was again significantly higher in the humic treatment than in the non-humic treatment. Bacterial production was somewhat higher in the humic treatment even on Day 1 of the experiment (Fig. 2; $p<0.001$ ). This might have been because of utilization of humic substances by bacteria. Between Days 1 and 5, there was an almost continuous decrease in bacterial production in both treatments, although rates were still higher in the humic treatment $(\mathrm{p}<$ 0.001 ). Between Days 5 and 9, the bacterial production rates increased to the levels they had had on Day 1 and, again, rates were higher in the treatment where humic substances had been added ( $p<0.001)$. Bacterial production rates were between 1 and $4 \%$ of primary production rates during the whole experiment.

\section{Phytoplankton numbers, growth rates and carbon content}

Some phytoplankton species/groups grew well and increased in number during the experiment, while others decreased because of grazing by copepods, nutrient limitation or other effects (e.g. containment effects). Diatoms (Leptocylindrus spp.) were initially stimulated by nutrient addition and had relatively high growth rates between Days 1 and $3\left(\mu=0.6\right.$ to $\left.0.8 \mathrm{~d}^{-1}\right)$ (Fig. 3). The growth rates are based on the cell counts and are therefore net growth rates in the presence of grazers. The number of diatoms then decreased during the latter part of the experiment. Small dinoflagellates also increased in number, and certain species (small Katodinium sp., Gymnodinium sp. and Amphidinium sp., all of them $<15 \mu \mathrm{m}$ ) continued to increase during the whole experimental period. Small dinoflagellates had significantly higher growth rates in the treatment where humic substances were added than they did in the non-humic treatment ( $\mathrm{p}<0.05$ ). The same pattern was seen for some of the large dinoflagellates [Gyrodinium sp. $(\mathrm{p}<0.05)$, Katodinium sp. (ns), Scripsiella trochoidea (ns) and Protoperidinium bipes $(\mathrm{p}<0.05)$ ] By contrast, however, some dinoflagellates (Ceratium fusus, C. furca, C. lineatum, Dinophysis norvegica and Prorocentrum micans) decreased in number during the experiment. Abundances of monads/flagellates, (counted in 3 size-fractions: $<3,3-6$ and $6-10 \mu \mathrm{m}$ ) increased rapidly during the first $5 \mathrm{~d}$ of the experiment (net growth, $\mu=0.3$ to $0.5 \mathrm{~d}^{-1}$ ) but after this their numbers decreased. On Day 9 of the experiment, their abundances were close to initial values, except for flagellates 3-6 $\mathrm{m}$, which remained at higher than initial abundance throughout the experiment.

The total phytoplankton biomass (as carbon), which was 34 to $49 \mathrm{\mu g} \mathrm{I}^{-1}$ initially, increased to 150 to $175 \mu \mathrm{g}$ $\mathrm{l}^{-1}$ on Day 5 , then decreased to levels of 90 to $140 \mathrm{\mu g} \mathrm{l}^{-1}$ by the end of the experiment. Phytoplankton carbon during the middle phase of the experiment (when the biomass was at its maximum) was dominated by diatoms (60 to $70 \%$ of phytoplankton carbon) while dinoflagellates made up approximately 10 to $20 \%$ of cell carbon (Fig. 3). At the end of the experiment, dinoflagellates made up 40 to $70 \%$ of phytoplankton carbon. The highest phytoplankton carbon concentrations were found in the treatment to which humic substances were added (on Day $3, p<0.01$ ). Other species/groups (not presented in Fig. 3) never comprised
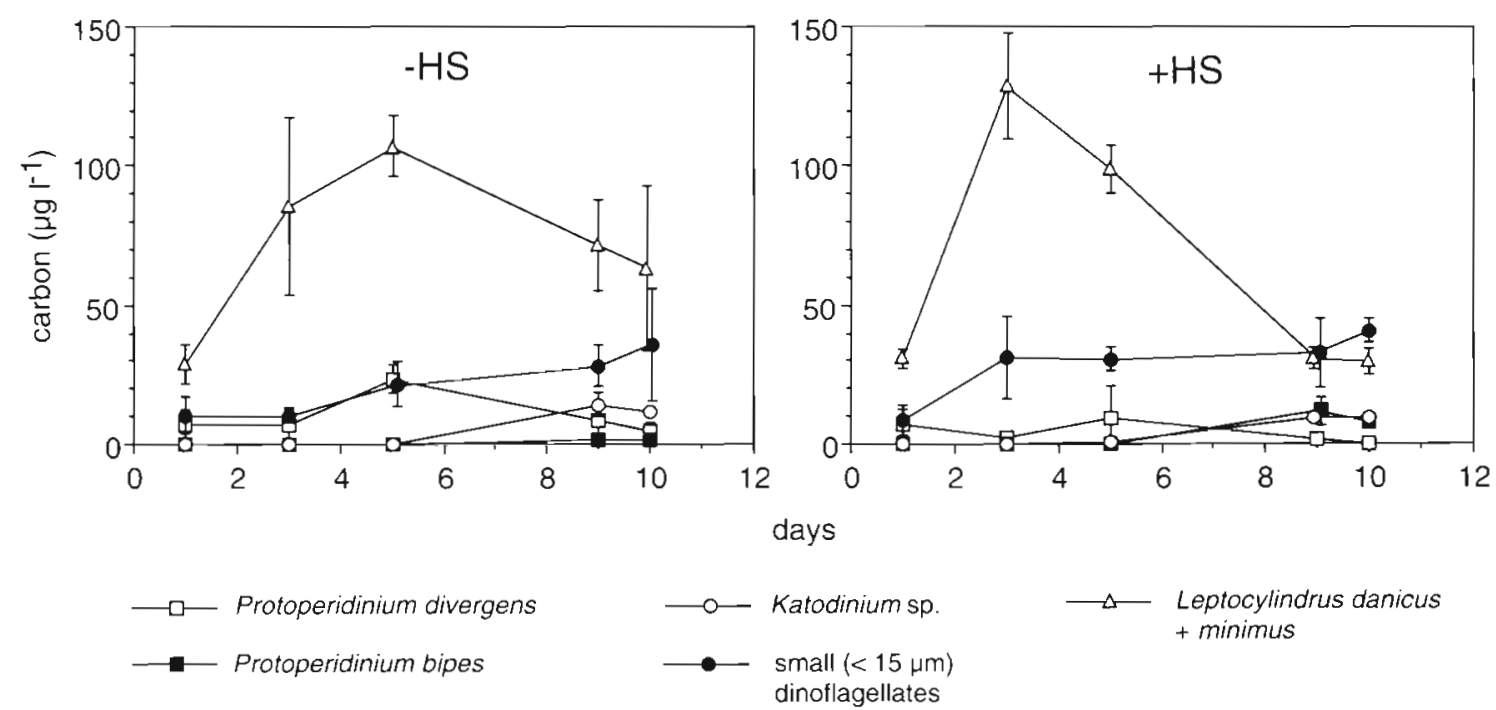

dinoflagellates

Fig. 3. Cell carbon concentration of dominant phytoplankton taxa in treatments with (+HS) or without (-HS) humic substances added. Carbon concentration was calculated by multiplying cell numbers with plasma volume (for diatoms) or cell volume (for other species) and using factors according to Smetacek (1975) and Strathmann (1967). Mean \pm SD of 8 replicates 
more than $6 \%$ of phytoplankton carbon during the experiment. The carbon:chlorophyll ratio was approximately 20 at the start of the experiment and increased to approximately 40 at Day 5 and 120 at Day 9.

\section{Protozooplankton}

The number of oligotrich ciliates was initially about 0.3 cells $\mathrm{ml}^{-1}$, and it increased in both treatments between Days 1 and 5. The increase was significantly larger in the humic treatment compared with the nonhumic treatment (Fig. 4). The number of oligotrich ciliates rose to approximately 15 cells $\mathrm{ml}^{-1}$ in the humic treatment, but to only 4.6 cells $\mathrm{ml}^{-1}$ in the non-humic treatment. The concentration of tintinnid ciliates was approximately 2 cells $\mathrm{ml}^{-1}$ on the first day of the experiment. The abundance of the tintinnids showed the same pattern as for the oligotrich ciliates. The number of tintinnids increased to approximately 15 cells $\mathrm{ml}^{-1}$ on Day 5 in the humic treatment, but to only 2 to 4 cells $\mathrm{ml}^{-1}$ in the non-humic treatment. After the initial increase of both oligotrich and tintinnid ciliates, their numbers decreased to initial levels over the last $5 \mathrm{~d}$ of the experiment.

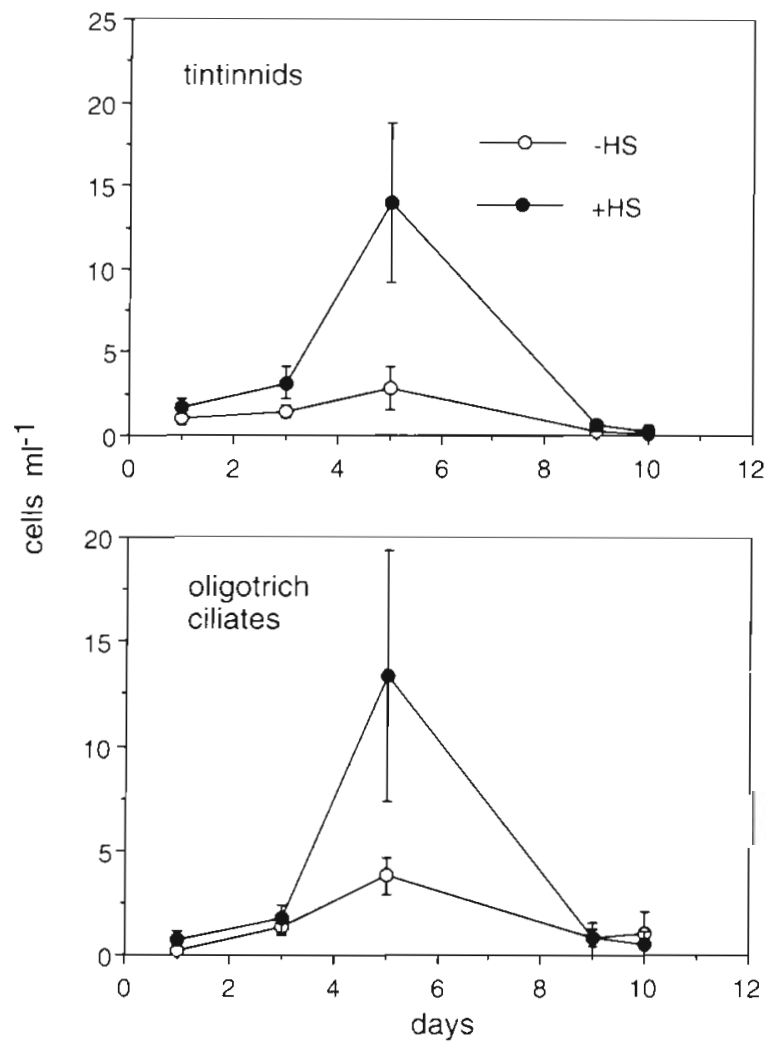

Fig. 4. Changes in cell numbers for tintinnics and oligotrich ciliates in treatments with $(+\mathrm{HS})$ or without $(-\mathrm{HS})$ humic substances added. Mean \pm SD of 8 replicates

\section{Copepods}

The natural concentration of copepods $(>100 \mu \mathrm{m})$ in the Gullmar Fjord was determined to be approximately 25 ind. $1^{-1}$. As more than $98 \%$ of all individuals were Oithona similis, only values for $O$. similis are presented here (Fig. 5). Between Days 1 and 9, the number of $O$. similis (copepods and copepodite stages $C_{1}$ to $C_{5}$ ) increased in both treatments. The number of nauplii increased from about 100 ind. $1^{-1}$ to about $500-600$ ind. $\mathrm{l}^{-1}$ during the first $3 \mathrm{~d}$. During the second part of the experiment, the nauplii decreased in both treatments. The number of copepodites and nauplii were significantly lower in the humic treatment than in the nonhumic treatment on Day $9(p<0.001)$.

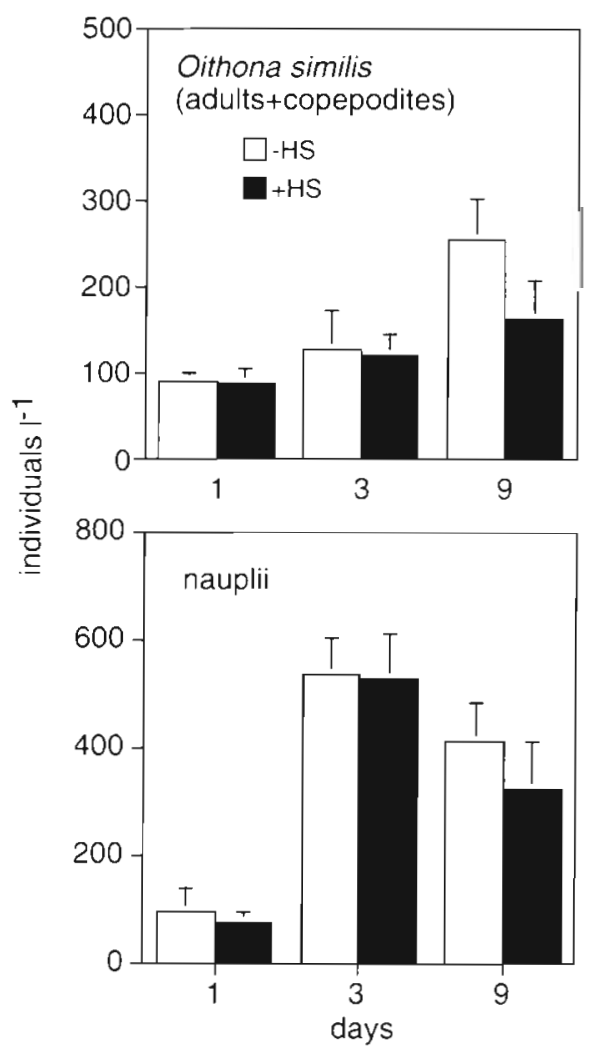

Fig. 5. Oithona similis. Number of copepods (adults and copepodite stages $C_{1}$ to $C_{5}$ ) and nauplii in treatments with (+HS) or without (-HS) humic substances added. Mean $\pm \mathrm{SD}$ of 8 replicates

\section{DISCUSSION}

In this experiment it was shown that several biological processes could be stimulated in near surface samples from the Gullmar Fjord when allochthonous DOM was supplied in relatively small quantities. Bacterial numbers and bacterial production were higher in the 
humic treatment than in the non-humic treatment throughout the experiment. This suggests that the humic substances were utilized by bacteria (Tranvik 1988, Moran \& Hodson 1990). Elsewhere, Chin-Leo \& Benner (1992) noted that DOM supplied by rivers increased bacterial production in coastal waters. According to the chl a measurements, there was a small, but significant, stimulation of phytoplankton growth by the addition of humic substances during the experiment. Assuming that $1 \mu \mathrm{mol} \mathrm{l}^{-1}$ of nitrogen is equivalent to the formation of $1 \mathrm{\mu g} \mathrm{l}^{-1}$ of $\mathrm{chl}$ a [which is an approximate value, but often typical of natural populations (Furnas 1983) or in monocultures under laboratory conditions (Harrison et al. 1977)], the nitrogen added with the addition of the humic substances $\left(3.6 \mu \mathrm{mol} \mathrm{l}^{-1}\right)$ should have been equivalent to the formation of $3.6 \mu \mathrm{g} \mathrm{l}^{-1}$ of chl a. The difference in the maximum attained chl a concentration between the humic and non-humic treatments was 1 to $2 \mu \mathrm{gl}^{-1}$ : chl a concentrations in the non-humic treatment reached 6 to 7 $\mu \mathrm{gl}^{-1}$, while in the humic treatment they reached over $8 \mu \mathrm{g} \mathrm{l}^{-1}$. This suggests that some of the humic nitrogen was incorporated by the phytoplankton (approximately 30 to $60 \%$ ). The rest of the nitrogen was either too refractory to be used, or might have been taken up by bacteria.

The C:N ratio in humic substances isolated from river water is usually around 50 (by weight) (Malcolm 1985). The humic substances used in this experiment had a $C: N$ ratio of approximately 56 . The $C: N$ ratio of particulate matter in coastal waters, by contrast, is generally much lower: between 4 and 20 according to Sakshaug et al. (1983). According to Fenchel \& Blackburn (1979), net mineralization of $\mathrm{N}$ will take place only when the bacterial substrate $C: N$ ratio is less than 10 (assuming a bacterial $\mathrm{C}: \mathrm{N}$ ratio of 5). Thus, when the substrate has a high $\mathrm{C}: \mathrm{N}$ ratio, as is the case for humic substances, assimilation of nitrogen, rather than mineralization, by bacteria is likely to occur. On the other hand, Tupas \& Koike (1990) have shown that ammonium was mineralized by marine bacteria when the $\mathrm{C}: \mathrm{N}$ ratio of the substrate was between 12 and 18 , but they did not study substrates with $\mathrm{C}: \mathrm{N}$ ratios higher than 18. Thus, some mineralization of nitrogen from humic substances might perhaps have occurred in this experiment. The most probable way for some part of the nitrogen from humic substances to have become available for phytoplankton, however, would have been via protozoan grazing on bacteria (Probyn 1987. Caron \& Goldman 1990).

The added humic substances increased the concentration of DOC from $5.0 \mathrm{mg} \mathrm{l}^{-1}$ to $7.8 \mathrm{mg} \mathrm{Cl}^{-1}$. The concentration of humic substances in surface water in the open Kattegat/Skagerrak is between 0.1 and $2.0 \mathrm{mg} \mathrm{C}$ $1^{-1}$ (Wedborg et al. 1994), but the concentrations are presumably higher in coastal areas. Thus, the amounts of humic substances added to the humic treatments were probably not large compared with either the amount of DOC already present in the water or the humic content of water from the central areas of the Kattegat/Skagerrak.

The rapid increase in phytoplankton biomass in spite of the high number of added copepods suggests that the copepods did not affect the growth of phytoplankton to any large extent. This might have been because Oithona similis, the dominant copepod species, is an omnivore (Paffenhöfer 1993) and may not have grazed on the phytoplankton very rapidly (Tsuda \& Nemoto 1988). If so, then perhaps the copepods may have been feeding on food sources other than phytoplankton. Another alternative food source might have been ciliates (e.g. Wiadnyana \& Rassoulzadegan 1989, Paffenhöfer 1993). Small flagellates (<3 and 3-6 $\mu \mathrm{m})$ increased in number during the experiment. These flagellates may have been too small to be grazed effectively (e.g. Tsuda \& Nemoto 1988).

The excretion of nitrogen by zooplankton might have provided a substantial source of nutrients in our experiment. The mean carbon weight of the Oithona individuals in our experiment was approximately $0.9 \mu \mathrm{g} \mathrm{C}$ ind.$^{-1}$ according to their mean prosome length of $600 \mu \mathrm{m}$ (S. Uye pers. comm.). If carbon weight was approximately $40 \%$ of the dry weight (Parsons et al. 1977), then dry weight of 1 Oithona individual would have been $2.25 \mu \mathrm{g}$. There are, to our knowledge, no measurements of excretion rates for Oithona, and weight-specific nitrogen excretion rates for mixed zooplankton/copepod communities vary between 0.17 and $4.5 \mu \mathrm{g} \mathrm{N} \mathrm{mg}$ dry $\mathrm{wt}^{-1} \mathrm{~h}^{-1}$ (prediction of weightspecific nitrogen regeneration rates based on linear regressions in Caron \& Goldman 1990 using data from Ikeda 1974, Mullin 1975, Ikeda et al. 1982, Vidal \& Whitledge 1982, and Verity 1985). Thus, over the course of the $10 \mathrm{~d}$ experiment, copepod excretion rate might have regenerated 0.5 to $14 \mu_{\mathrm{mol}} \mathrm{l}^{-1}$ with a concentration of approximately 80 copepods $\mathrm{I}^{-1}$ In addition microzooplankton would also have contributed to the regenerated nitrogen pool. The number of tintinnids and ciliates peaked on Day 5 of the experiment $\left(\sim 15\right.$ cells $\left.\mathrm{ml}^{-1}\right)$. Their cell volumes $\left(-3000 \mathrm{\mu m}^{3}\right.$, and $15000 \mu^{3} \mathrm{~m}^{3}$ cell ${ }^{-1}$ respectively) were converted to dry weight by assuming a specific gravity of 0.2 (Caron \& Goldman 1990). Excretion rates were assumed to be 1 to $10 \mu \mathrm{g} \mathrm{N}$ mg dry $\mathrm{wt}^{-1} \mathrm{~h}^{-1}$ (Verity 1985). Thus, maximum ciliate excretion of nitrogen during the $10 \mathrm{~d}$ experiment would have been 1 to $9 \mu_{\mathrm{mol} \mathrm{l}}^{-1}$. Heterotrophic nanoflagellates also probably excreted nitrogen, but, since their numbers were not determined, we cannot estimate their contribution. The regenerated nitrogen might thus have been between 1.5 and 
23 umol $\mathrm{l}^{-1}$ during $10 \mathrm{~d}$. Since there was no net accumulation of either inorganic nitrogen, phytoplankton biomass or increase in copepod numbers, the amount of regenerated nitrogen may have been in the lower part of this range. Thus, the nitrogen regenerated by grazers might have been comparable to the nitrogen added as humic substances. Also, the nitrogen excreted by grazers and its uptake by phytoplankton must have been tightly coupled, since inorganic nitrogen did not accumulate.

During the first $4 \mathrm{~d}$ of the experiment silicate concentrations dropped ( 0.4 to $\left.0.5 \mu \mathrm{mol} \mathrm{l}^{-1}\right)$ to levels which would have caused silicon limitation for the diatoms: silicon half saturation constants are in the range 0.3 to $5 \mu \mathrm{mol} \mathrm{l}^{-1}$ (Paasche 1980). Microscopic observations of the diatoms also showed that the diatom cell walls became thinner during the experiment and that by the end of the experiment Leptocylindrus danicus and $L$. minimus cells were abnormally shaped (twisted and bent)

The low concentration of inorganic nitrogen and the presence of excess phosphorus, trace metals and vitamins suggests that phytoplankton growth became nitrogen limited between Days 3 and 4 of the experiment. Increasing nitrogen limitation was accompanied by decreasing chl a concentrations in all treatments. This may have affected the copepods. Uchima \& Hirano (1986) found that nauplii of Oithona davisae need a food concentration of at least $270 \mu \mathrm{g} \mathrm{C}^{-1}$ to develop into first stage copepodites. Since the phytoplankton carbon concentration in both treatments was below $200 \mu \mathrm{g} \mathrm{Cl}^{-1}$ after Day 5 during the experiment, food limitation probably occurred.

At the end of the experiment, there were significantly lower numbers of adults/copepodites and nauplii in the humic treatment than in the non-humic treatment. The reason for the difference is unknown.

In conclusion, grazing by Oithona similis, which is the dominant copepod species in the eastern Skagerrak between July and September (Eriksson 1976), did not affect the phytoplankton biomass to any large extent, even if the copepods were added at 3 times the ambient density. This may be because of its omnivorous feeding behaviour. Bacteria were able to utilize allochthonous humic substances rapidly and the activity in the 'microbial loop' was increased. Also the growth of phytoplankton, especially small dinoflagellates and heterotrophic dinoflagellates, was to a minor extent stimulated, but no positive reaction could be noted at the copepod level.

Acknowledgements. This study was supported by funds from the Swedish Natural Science Research Council (NFR), the Swedish Environmental Protection Agency, the Carl Trygger Foundation, Stockholm. The Royal Physiographic Society and the Crafoord Foundation, Lund, Sweden. We thank Måns Lin- dell and Henric Linge (Department of Limnology, Lund) for helping us with the field work and the thymidine incorporation measurements and Christer Nylander (Department of Marine Ecology, Lund) for statistical assistance. Wilhelm Granéli (Department of Limnology, Lund) and 3 anonymous reviewers made valuable comments on earlier versions of the manuscript

\section{LITERATURE CITED}

Ertebjerg-Nielsen G, Bresta AM (1984) Guidelines for the measurement of phytoplankton primary production, 2nd edn. BMB Publ no 1. The Baltic Marine Biologists, Charlottenlund

Andersson T, Nilsson $\AA$, Jansson M (1991) Coloured substances in Swedish lakes and rivers - temporal variation and regulating factors. In: Allard B, Borén $\mathrm{H}$, Grimvall A (eds) Humic substances in the aquatic and terrestrial environment. Lecture Notes in Earth Sciences, Vol 33 Springer-Verlag, Berlin, p 243-253

Azam F, Fenchel T, Field JG, Gray JS, Meyer-Reil LA, Thingstad $F$ (1983) The ecological role of water column microbes in the sea. Mar Ecol Prog Ser 10:257-273

Bamstedt U (1985) Seasonal excretion rates of macrozooplankton from the Swedish west coast. Limnol Oceanogr 30:607-617

Carlson RE, Shapiro J (1981) Dissolved humic substances: a major source of error in fluorometric analyses involving lake waters. Limnol Oceanogr 26:785-790

Carlsson P. Granéli E (1993) Availability of humic bound nitrogen for coastal phytoplankton. Estuar coast Shelf Sci $36: 433-447$

Carlsson P, Segatto AZ, Granéli E (1993) Nitrogen bound to humic matter of terrestrial origin - a nitrogen pool for coastal phytoplankton? Mar Ecol Prog Ser 97:105-116

Caron DA, Goldman JC (1990) Protozoan nutrient regeneration. In: Capriulo GM (ed) Ecology of marine protozoa. Oxford University Press, New York, p 283-306

Chin-Leo G, Benner R (1992) Enhanced bacterioplankton production and respiration at intermediate salinities in the Missisippi River plume. Mar Ecol Prog Ser 87:87-103

Chrost RJ, Münster U, Rai H, Albrecht D, Witzel PK, Overbeck J (1989) Photosynthetic production and exoenzymatic degradation of organic matter in the euphotic zone of a eutrophic lake. J Plankton Res 11:223-242

Davis CS, Gallager SM, Solow AR (1992) Microaggregations of oceanic plankton observed by towed video microscopy Science 257:230-232

Edler L (ed) (1979) Recommendations on methods for marine biological studies in the Baltic Sea - phytoplankton and chlorophyll. BMB Publ no 5. The Baltic Marine Biologists, Lund

Eriksson S (1976) Seasonal and temperature occurrences of neritic copepods on the Swedish west coast. Zoon 4 $155-160$

Fenchel T, Blackburn TH (1979) Bacteria and mineral cycling. Academic Press, London

Flynn KJ, Butler I (1986) Nitrogen sources for the growth of marine microalgae: role of dissolved free amino acids. Mar Ecol Prog Ser 34: 281-304

Fuhrman JA, Azam F (1980) Bacterioplankton secondary production estimates for coastal waters off British Columbia, Antarctica, and California. Appl environ Microbiol 39: 1085-1095

Fuhrman JA, Azam F (1982) Thymidine incorporation as a measure of heterotrophic bacterioplankton production in 
marine surface waters: evaluation and field results. Mar Biol 66:109-120

Furnas MJ (1983) Nitrogen dynamics in lower Narragansett Bay, Rhode Island. I. Uptake by size fractionated phytoplankton populations. J Plankton Res 5:657-676

Geller A (1983) Degradability of dissolved organic lake water compounds in cultures of natural bacterial communities. Arch Hydrobiol 99:60-79

González HE, Smetacek V (1994) The possible role of the cyclopoid copepod Oithona in retarding vertical flux of zooplankton faecal material. Mar Ecol Prog Ser 113: $233-246$

Guillard RRL, Ryther JH (1962) Studies of marine planktonic diatoms I. Cyclotella nana Hustedt, and Detonula confervacea (Cleve) Gran. Can J Microbiol 8:229-239

Harrison PJ, Conway HL, Holmes RW, Davis CO (1977) Marine diatoms grown in chemostats under silicate or ammonium limitation 1II. Cellular chemical composition and morphology of Chaetoceros debilis, Skeletonema costatum, and Thalassiosira gravida. Mar Biol 43:19-31

Heinänen A (1993) Measuring thymidine incorporation in the open Baltic Sea, a temperate brackish water estuary: comments on saturation level of thymidine. Arch Hydrobiol $127: 289-298$

Ikeda T (1974) Nutritional ecology of marine zooplankton. Mem Fac Fish Hokkaido Univ 22:1-97

lkeda T, Fay EH, Hutchinson SA, Boto GM (1982) Ammonia and inorganic phosphate excretion by zooplankton from inshore waters of the Great Barrier Reef, Queensland. I. Relationship between excretion rates and body size. Aust $\mathrm{J}$ mar Freshwat Res 33:55-70

Jespersen AM, Christoffersen K (1987) Measurements of chlorophyll-a from phytoplankton using ethanol as extraction solvent. Arch Hydrobiol 109:445-454

Kieber RJ, Zhou X, Mopper K (1990) Formation of carbonyl compounds from UV-induced photodegradation of humic substances in natural waters: fate of riverine carbon in the sea. Limnol Oceanogr 35:1503-1515

Larsson U, Hagström $\AA$ (1979) Phytoplankton exudate release as an energy source for the growth of pelagic bacteria. Mar Biol 52:199-206

Malcolm RL (1985) Geochemistry of stream fulvic and humic substances. In: Aiken GR, McKnight DM, Wershaw RL (eds) Humic substances in soil, sediment, and water. John Wiley \& Sons, New York, p 181-210

Moran MA, Hodson RE (1990) Bacterial production on humic and nonhumic components of dissolved organic carbon. Limnol Oceanogr 35:1744-1756

Mullin MM, Perry MJ, Renger EH, Evans PM (1975) Nutrient regeneration by oceanic zooplankton: a comparison of methods. Mar Sci Comm 1:1-13

Paasche E (1980) Silicon. In: Morris I (ed) The physiological ecology of phytoplankton. Studies in ecology, Vol 7 . Blackwell Scientific Publications, Oxford, p 259-284

Paffenhöer GA (1993) On the ecology of marine cyclopoid copepods (Crustacea, Copepoda). J Plankton Res 15: $37-55$

Parsons TR, Takahashi M. Hargrave B (1977) Biological oceanographic processes, 2nd edn. Pergamon Press, Oxford, p 40-64

Petersen RC Jr, Hargeby A, Kullberg A (1987) The biological importance of humic material in acidified waters. National Swedish Environmental Protection Board, Stockholm, Rep 3388

Porter KG, Feig YS (1980) The use of DAPI for identifying and counting aquatic microflora. Limnol Oceanogr 25:943-948
Probyn TA (1987) Ammonium regeneration by microplankton in an upwelling environment. Mar Ecol Prog Ser 37:53-64

Rashid MA (1985) Geochemistry of marine humic compounds. Springer-Verlag, New York

Sahlsten E, Sörensson F, Petterson K (1988) Planktonic nitrogen uptake in the south-eastern Kattegat. J exp mar Biol Ecol 121:227-246

Sakshaug E, Andresen K, Myklestad S, Olsen Y (1983) Nutrient status of phytoplankton communities in Norwegian waters (marine, brackish, and fresh) as revealed by their chemical composition. J Plankton Res 5:175-196

Santschi PH (1982) Application of enclosures to the study of ocean chemistry. In: Grice GD, Reeve MR (eds) Marine mesocosms. Springer-Verlag. New York, p 63-80

Smetacek V (1975) Die Sukzession des Phytoplankton in der westlichen Kieler Bucht. PhD thesis, Institut für Meereskunde, Kiel

Solórzano L, Sharp J H (1980) Determination of total dissolved nitrogen in natural waters. Limnol Oceanogr 25:751-754

Strathmann RR (1967) Estimating the organic carbon content of phytoplankton from cell volume or plasma volume. Limnol Oceanogr 12:411-418

Thurman EM (1985) Organic geochemistry of natural waters. Martinus Nijhoff/Dr W Junk Publishers, Boston

Thurman EM, Malcolm RL (1981) Preparative isolation of aquatic humic substances. Environ Sci Technol 15: $463-466$

Tranvik LJ (1988) Availability of dissolved organic carbon for planktonic bacteria in oligotrophic lakes of differing humic content. Microb Ecol 16:311-322

Tsuda A, Nemoto T (1988) Feeding of copepods on natural suspended particles in Tokyo Bay, Japan. J oceanogr Soc Japan 44:217-227

Tupas L, Koike I (1990) Amino acid and ammonium utilization by heterotrophic marine bacteria grown in enriched seawater. Limnol Oceanogr 35:1145-1155

Uchima $M$ (1988) Gut content analysis of the neritic copepods Acartia omorii and Oithona davisae by a new method. Mar Ecol Prog Ser 48:93-97

Uchima M, Hirano M (1986) Predation and cannibalism in neritic copepods. Bull Plankton Soc Jpn 33:147-149

UNESCO (1983) Chemical methods for use in marine environmental monitoring. Intergovernmental Oceanographic Commission, Paris, Manuals and guides, no. 12

Utermöhl H (1958) Zur Vervollkomnung der quantitativen Phytoplankton Methodik. Mitt int Verein theor angew Limnol 9:1-38

Vadstein O, Harkjerr BO, Jensen A, Olsen $Y$, Reinertsen $H$ (1989) Cycling of organic carbon in the photic zone of a eutrophic lake with special reference to the heterotrophic bacteria. Limnol Oceanogr 34:840-855

Verity PG (1985) Ammonia excretion rates of oceanic copepods and implications for estimates of primary production in the Sargasso Sea. Biol Oceanogr 3:249-283

Vidal J, Whitledge TE (1982) Rates of metabolism of planktonic crustaceans as related to body weight and temperature of habitat. J Plankton Res 4:77-84

Wedborg M, Skoog A, Fogelquist E (1994) Organic carbon and humic substances in the Baltic Sea, the Kattegat, and the Skagerrak. In: Senesi N, Miano TM (eds) Humic substances in the global environment and implications on human health. Elsevier Science Publishing Co, Amsterdam, p $917-924$

Wiadnyana NN, Rassoulzadegan F (1989) Selective feeding of Acartia clausii and Centropages typicus on microzooplankton. Mar Ecol Prog Ser 53:37-45

Manuscript first received: September 7, 1993

Revised version accepted: May 3, 1995 